\title{
3 Community Priorities for Water Rights: Some Conjectures on Assumptions, Principles and Programmes
}

\author{
Bryan Bruns \\ Santa Rosa Beach, Florida, USA; e-mail: bryanbruns@bryanbruns.com
}

\begin{abstract}
Increasing policy support for community participation in natural resources management has been challenged by questions about the feasibility, risks and results of such approaches. The application of participatory approaches for improving basin-scale water governance should be considered in light of critical analysis of community-based natural resources management and institutional design principles for common-property resources management. Problems of conflicting interests and contextual contingency (politics and history) illustrate the need for revising assumptions and expectations. A community perspective on principles for institutional design leads to distinct priorities for improving basin water allocation. Measures to support community involvement in basin water governance - such as legislative reform, legal empowerment, networking, advocacy, participatory planning, technical advice and facilitation - should be formulated to fit community priorities for negotiating rights to water.

Keywords: water rights, water allocation institutions, river basin, governance, integrated water resources management, community-based natural resources management, institutional design principles.
\end{abstract}

\section{Introduction}

As governments and other organizations seek to improve the management of natural resources, participatory and community-based approaches have promised valuable advantages, and so they have received increasing support in the policies of national and international agencies. However, evidence and analysis indicate that the application of such approaches also faces serious challenges and constraints; see, for example, Agrawal and Clark (2001); Knox and Meinzen-Dick (2001); Ribot (2002); Young (2002); Agrawal (2003); Cleaver and Franks (2003); Mosse (2003); Sengupta (2004); Mansuri and Rao (2005);
Shah, Chapter 5, this volume. This chapter looks at the relevance of community-based approaches to the negotiation of water rights within basin water governance, considered in the light of critical analysis of community-based natural resources management and of institutional design principles for common-property resources management. It applies a community perspective to identify practical implications for revising assumptions about community participation, customizing application of institutional design principles and formulating more effective programme interventions.

Rights to water may be negotiated in many contexts (Bruns and Meinzen-Dick, 2000, 2001), not only within communities ${ }^{1}$ but also 
between communities sharing rivers, aquifers and other common-pool water resources. Government assistance in developing irrigation and water supply systems may require agreements limiting how much water will be abstracted, as well as allocating access to enhanced supplies. As competition for water rises along rivers, water users may take part in deciding how scarce water will be shared between users within a sub-basin or basin. If government agencies seek to formalize water rights, then quantities and conditions in permits and plans may be negotiated. One source of water to supply the demands of growing cities may come through voluntary agreements that compensate irrigators for transfers. These situations not only offer important opportunities for government intervention in basin-scale water allocation but also present opportunities and challenges for communities.

From the perspective of rural communities, negotiating agreements about rights to water may be a necessary condition for aid in improving water supplies to farms and homes. More likely, though, is the need to defend access to water against threats from competing users. Drought intensifies conflicts, stimulating shortand long-term efforts to modify rules and procedures regulating rights to water. New projects for urban water supply or irrigation may take water away from existing users. Bureaucratic programmes, such as basin planning or registration of water rights, pose risks where rights will be impaired or lost unless water users act effectively to protect themselves. Legislative changes may imperil customary community-based water rights, denying them legal status or forcing fragmentation of rights.

Communities may respond by employing multiple strategies in various arenas, such as: (i) acting directly to acquire more water or block others' access; (ii) participating in planning and other formal administrative procedures; (iii) litigating in courts; (iv) lobbying to advocate their case to the public and politicians; and (v) pursuing agreements with other water users and with water management agencies. ${ }^{2}$ Negotiation frequently plays an important part in such strategies, whether agreements are sought immediately or worked out later to settle disputes initially fought in other arenas. More broadly, government interventions in water allocation and community efforts to defend access to water create situations where water rights are negotiated.

Table 3.1 summarizes key contexts for negotiation of water rights, highlighting differences between situations that governments may see as opportunities for intervention to serve societal goals compared to what communities may see as threats to their rights to water. Such situations, as perceived and prioritized by communities, then provide contexts for reconsidering assumptions underlying community participation, principles for institutional design and formulation of programme interventions.

Participatory and community-based approaches to natural resources management promise important advantages in the development institutions for water allocation at subbasin- and basin-scale but, as outlined in the next section of this chapter, limitations of politics and history should be expected to constrain and complicate their implementation. While general institutional design principles for the management of common-property resources have been proposed, the following section shows how a community perspective on the application of such principles to basin governance identifies priorities distinctly different from generic recommendations. Similarly, measures intended to support communities may fail to achieve intended results, unless adjusted to fit local circumstances and priorities, as discussed in the section on aiding community negotiation of this chapter. The final section of the chapter summarizes conjectures about community dynamics and priorities in securing access to water.

Table 3.1. Key contexts from two perspectives on negotiating water rights in river basins.

\begin{tabular}{ll}
$\begin{array}{l}\text { Government perspective } \\
\text { (Opportunities for } \\
\text { intervention) }\end{array}$ & $\begin{array}{l}\text { Community perspective } \\
\text { (Defence against } \\
\text { threats) }\end{array}$ \\
\hline $\begin{array}{l}\text { Assistance-improvement } \\
\text { projects }\end{array}$ & $\begin{array}{l}\text { Competition for water } \\
\text { Basin allocation } \\
\text { Reallocation } \\
\text { Formalization of rights }\end{array}$ \\
& $\begin{array}{l}\text { Drought } \\
\text { Expropriation } \\
\text { Denial or fragmentation } \\
\text { of rights }\end{array}$ \\
\hline
\end{tabular}




\section{Advantages and Limitations of Community-based Approaches}

Top-down approaches, emphasizing centralized government authority and control, have dominated most government efforts to manage water and other natural resources. There is now increased interest in, and support for, participatory and community-based approaches to natural resources management and conservation that may help address some of the limitations, disappointments and problems associated with top-down approaches (Knox and Meinzen-Dick, 2001; Ribot, 2002; Mosse, 2003). Participation may cover a range of interactions between decision makers and stakeholders, ranging from minimal dissemination of information, through consultation that listens to stakeholder inputs, involvement in dialogue, collaborative development of alternatives, joint decision making in co-management and delegation of specific authority and empowerment of communities to make autonomous or independent decisions. ${ }^{3}$

The rhetoric of community-based resources management often suggests strong devolution of authority, empowering communities to make decisions on their own, perhaps with some technical guidance and support from outside. ${ }^{4}$

However, in practice what often occurs are more limited forms of participation, for example where government approval for detailed management plans is required, or where mutual consensus for co-management, or agreements, or even narrower forms of stakeholder involvement with final authority for decisions remaining fully with government agencies, are necessary. Participation is used in this chapter as a general term for a variety of institutional arrangements that involve stakeholders in decisions, while community-based refers to arrangements that provide primary decisionmaking power to communities, either local governments or specialized organizations of resource users such as water user associations.

Participatory and community-based approaches may be valued for their own sake, as ways to support local cooperation and self-governance. Such approaches may also be pursued for practical reasons, for example as instruments to increase equity or raise water productivity, as ways to reduce transactions costs or simply as a means to shift costs away from government. Such approaches can utilize local knowledge in crafting management measures to match local conditions. Many of the advantages of these approaches potentially apply not just within communities but also in the situations that are the primary concern of this chapter, where water rights may be negotiated between communities as part of basin water management:

- Water users possess detailed local knowledge about how they use water, their needs and the possible consequences of changes. Community-based approaches cultivate channels through which this information can be considered in making decisions.

- Collective action to manage water weaves water users together in webs of relationships. These relationships can build social capital of trust and shared understanding that facilitates cooperation, at both local and larger scales.

- As part of their daily activities, it is often easy for water users to observe whether neighbours are fulfilling their commitments and obligations in using water. They can monitor and detect nearby violations with relatively little time and effort.

- Communities can selectively apply sanctions unavailable through formal institutions. The threat of being shamed or of losing one's reputation as respected and trustworthy may compel compliance. Water users possess strong incentives and willingness to struggle for their access to water.

- Community-based approaches may be able to resolve many conflicts at a local level, by those most concerned, with less cost or complication. Such subsidiarity, customized to local circumstances, reduces the transaction costs of coordinating resource use and implementing agreements.

- Involving communities in decisions builds legitimacy and support, reducing risks of rejection and resistance. Participation realizes principles of democracy and empowerment.

- Water management may become more effective when it utilizes the capabilities of users, not only as individuals but also as communities linked by ongoing relationships, with shared views and common interests that facilitate cooperation. 
However, participatory and community-based approaches have been the subject of growing critical scrutiny. ${ }^{5}$ Community-based approaches have frequently been applied with unrealistic assumptions and expectations. They have sometimes been advocated and applied with inadequate attention to the variety of people involved in using and managing resources in local areas, and the intricate arrangements through which they compete and cooperate. Simplistic stereotypes of isolated, small, stable and homogeneous groups sharing the same interests and traditional norms for preserving local resources often fit poorly with the complexity of how diverse local and external actors struggle to make and break rules about exploiting and replenishing resources that may be mobile and interconnect broad areas (Agrawal and Gibson, 2001). The conditions and limitations of community-based approaches need to be considered along with their advantages, within particular contexts. Critiques of community-based natural resources management concentrate on core themes of conflict, differences between actors, incentives and contextual contingency.

\section{Conflict}

The concept of community itself is problematic, presuming local solidarity and cooperation that may be absent or achieved only through exceptional effort. Romanticism and ideological aspirations risk obscuring recognition of the tensions, strife and flaws that characterize collective action, past and present. Thus, for example, accounts portraying Balinese subaks and other irrigation communities as highly cohesive encourage exaggerated assumptions about what exists or may be feasible for water user associations. ${ }^{6}$ Access to water and other resources is politically contested, so 'management' is not purely a neutral technical exercise in optimizing water productivity but also a process of continuing struggle among competing claimants. Incentives to take part in collective action depend on, among other things, the distribution of anticipated benefits and costs, and conflicts about the distribution of gains and losses can obstruct agreement about defining rights and arranging cooperation.

\section{Heterogeneity}

Assumptions of homogeneous actors are invalid, with gender, age, wealth and other distinctions differentiating communities internally. Within an irrigation system, head-enders have different interests and options than tail-enders. Similarly, communities differ from one another in resources, livelihoods, organizational capacity and other characteristics. Theoretical and empirical analyses indicate that heterogeneity may impede or facilitate collective action (Olson, 1971; Mansuri and Rao, 2005), but diverse situations of different actors inevitably shape perceptions and actions. Collective action is not simply a matter of aggregating identical interests but one of forging coalitions among diverse participants.

\section{Asymmetry}

Differences in knowledge, wealth, power and other characteristics matter not only within communities but also in wider interactions. Such asymmetries often (but not always) place communities at a disadvantage in negotiating with outside water users. Communities, especially rural communities, may have little room for manoeuvre beyond compliance or muted resistance. If an opportunity exists to negotiate, they may have few alternatives for maintaining or improving their access to resources, leaving them in a weak bargaining position. ${ }^{7}$

\section{Inequity}

Aid that may help people who are generally poor by national standards does not necessarily do much for those who are the poorest. Biased decisions may reinforce and worsen inequities in access to resources (Mansuri and Rao, 2005). Poor people, women, ethnic minorities, youths and elderly, and others who are not part of local elites may be left out and their views and concerns neglected unless special outreach efforts are arranged. However, a degree of control by local elites, although not necessarily 'capture,' seems almost inevitable. ${ }^{8}$

Within communities, it may not be realistic to expect community-based approaches to reduce inequalities, unless specific conditions 
and measures direct change in pro-poor directions. Specific targeting measures may help to provide more benefits for those who are poorer. In general, rather than idealistically assuming that community-based approaches will automatically or necessarily favour equality or yield 'pro-poor' results, a more realistic assumption may be that community-based approaches are likely to reproduce existing inequalities, and may even worsen them, unless offset by countervailing conditions and measures.

\section{Local incentives}

Participation imposes substantial transaction costs, particularly for the poor, and may not be worthwhile for participants. This is due not only to problems in organizing collective action but also to the risks of manipulated and meaningless participation, and policies that transfer responsibility without authority. Furthermore, the incentives of both leaders and ordinary resource users are not necessarily consistent with conservation and sustainable use. In practice, transfer to local control may be almost as prone to biased access and neglect of longer-term sustainability as state control of resources, unless adequately offset by local and external regulation to promote broader societal interests, such as legal equality, social equity and environmental conservation (Ribot, 2002). Rather than simplistic state withdrawal for full local control, the need may be to find an institutional mix that better combines community, market and state action, as in forms of co-production, co-management or regulated autonomy. ${ }^{9}$

\section{Context}

The complexity of local resource characteristics, social relationships, external linkages and other circumstances conditions the impact of interventions, making them prone to fail unless carefully customized to context (Mansuri and Rao, 2005). Communities have been, and will continue to be, strongly shaped by external linkages including trade, migration, politics and culture (Wolf, 1983). Potential pathways for change are shaped by existing conditions.

Uniform implementation and outcomes are unlikely. Attempts to impose solutions from outside often founder because they fit poorly with local resource characteristics and institutions ${ }^{10}$ and are resisted as inappropriate and illegitimate. Existing institutional arrangements shape perceptions and the potential for modifying or replacing rules, so that paths for change depend on past and present perceptions and practices that are not easily altered. Institutional rearrangements that occur under exceptional circumstances, such as outstanding local leaders, strongly integrated communities, abundant funding and skilled advice are hard to replicate, and prone to revert when the unusual circumstances disappear (Bruns, 1992; Shah, Chapter 5, this volume).

In simple terms, politics and history condition what is possible. These factors influence the applicability of community-based approaches to natural resources management in general and to water allocation in particular. Community-based approaches are not a panacea: they do not offer a way to escape politics, bypass elites or safely shortcut to social justice. However, the thrust of most critiques is not to say that communitybased management is impossible, but rather to challenge invalid assumptions, oversimplified implementation and unrealistic expectations. Revised assumptions, as summarized in Table 3.2 , and further discussed below, may provide a more realistic foundation for community-based approaches.

\section{Applying Institutional Design Principles}

One important source of ideas about communitybased natural resources management comes from research on common-pool resources, such as forests, fisheries, rangeland and irrigation systems. Principles of institutional design, as summarized in the first column of Table 3.3, have synthesized findings from analysis of long-enduring institutions managing common-property resources (Ostrom, 1990). The principles identify means to overcome the 'tragedy of the [unmanaged] commons', where individual self-seeking behaviour would degrade shared resources, unless regulated through suitable institutional arrangements. ${ }^{11}$ Research on such arrangements has documented the potential for successful selfgovernance (Hardin, 1968; 1988).

Resource users, acting as insiders, design institutions through various conscious and unconscious processes including deliberate rule 
Table 3.2. Revising assumptions for community-based natural resources management (CBNRM).

\begin{tabular}{ll}
\hline Conventional & Critical \\
\hline Community solidarity & Conflicting interests, coalitions \\
Homogeneity & Heterogeneity \\
Equality & Asymmetry \\
Technical optimization & Political contestation \\
Equitable outcomes & Reproduction of inequities unless countervailed \\
Independence & Regulated autonomy \\
Self-sufficiency & Interlinkages \\
Replicable intervention & Contextual (path dependent, ergodic, bricolage, \\
& improvised, episodic, adaptive, experimental) \\
\hline
\end{tabular}

making, imitation, trial and error learning and improvisation. While detailed local rules for resource use vary widely, the design principles summarize general patterns. Many studies of common property have focused on small communities, apparently managing resources through relatively autonomous self-governance, often analytically treated as relatively homogeneous and isolated from external political and economic forces. Such relatively simple conditions ease theoretical analysis. The principles emphasize 'long-enduring' institutions, able to recover from shocks and adapt to changing conditions, especially since there may be no stable ecological equilibrium and no 'one best way' to manage a resource (Ostrom, 1999; Anderies et al., 2003).

Further analysis has challenged simplistic interpretations of institutional design principles. Research has highlighted differentiation within communities, interactions with external social and economic forces and implications of resources and livelihood strategies that extend beyond small localities (Agrawal, 2003). The capacity of government intervention to disrupt local institutions for managing common property resources has been extensively documented, but less has been learned about ways that states can support and sustain local management (Sengupta, 2004).

Attempts to apply the principles of institutional design to prescriptively determine how institutions for river basin water allocation must be designed may fit badly with the complexity of local history and politics (Cleaver and Franks, 2003; Ravnborg, 2004 (cited with permission)). Institutional change may be less a process of careful and deliberate craftsmanship, and more a messy process of institutional bricolage, an improvised recombination of available arrangements. ${ }^{12}$ Thus, application of institutional design principles needs to take into account the influence of politics, history and the improvisational and contested ways in which institutions are modified, as well as incomplete information and uncertainty about outcomes of modifying complex systems.

Nevertheless, within an appropriately contextualized approach, institutional design principles usefully outline key challenges facing stakeholders concerned with governing shared water resources. While institutional design principles are insufficient by themselves to devise solutions, they provide a framework for analysing some of the challenges facing communities seeking to negotiate rights to water in contexts of competition with other communities and significant state influence on water governance. ${ }^{13}$ Based on experience and analysis of common property resources management in general, and water allocation in particular, some preliminary ideas can be proposed about priorities for communities negotiating rights to water.

\section{Clearly defined boundaries}

Watersheds delimit catchments within which water flows into streams that merge to form rivers, delineating sub-basins and basins that appear to clearly define boundaries for water management. As water becomes scarcer in a basin, the scope of interaction and competition between users increases, increasing the need for, and potential benefits from, coordination among those sharing a common resource. 
Table 3.3. Institutional design principles, issues and conjectures on community priorities (The first column repeats 'design principles derived from studies of long-enduring institutions for governing sustainable resources', as presented in Anderies et al., 2003, which was based on Ostrom, 1990, p. 90. For column two, see this chapter, and also Cleaver and Franks, 2003 and Ravnborg, 2004).

\begin{tabular}{lll}
\hline Principle & Issues & Community priorities \\
\hline Clearly defined boundaries & Basins offer clear boundaries, but: & Coalitions for problemsheds \\
The boundaries of the resource & shortages are uncertain and & \\
system (e.g. irrigation system or & concentrated in particular times and & \\
fishery) and the individuals or & places; administrative boundaries, & \\
households with rights to harvest & livelihood activities and other & \\
resource units are clearly defined & linkages cross-cut basins &
\end{tabular}

Proportional equivalence between benefits and costs

Rules specifying the amount of resource products that a user is allocated are related to local conditions and to rules requiring labour, materials and/or money inputs.

Volumetric allocation difficult and expensive; infrastructural subsidies distort linkages between receiving water and paying costs

Scale makes representation necessary; platforms may be biased, manipulated or lack authority

Agency accountability weak; complex factors affect basin water availability; information technologies make more information available, but threaten information overload

\section{Graduated sanctions}

Users who violate rules-in-use are likely to receive graduated sanctions (depending on the seriousness and context of the offence) from other users, from officials accountable to these users or from both.

\section{Low-cost conflict-resolution} mechanisms

Users and their officials have rapid access to low-cost, local arenas to resolve conflicts among users or between users and officials

\section{Minimal recognition of rights to organize}

The rights of users to devise their own institutions are not challenged by external governmental authorities, and users have long-term tenure rights to the resource

\section{Nested enterprises}

(for resources that are parts of larger systems)

Appropriation, provision, monitoring, enforcement, conflict resolution and governance activities are organized in multiple layers of nested enterprises
Lack of relationships between

distant users impedes trust and informal sanctions; formal sanctions hard to enforce

Courts problematic for resolving water conflicts

National legal frameworks ignore or disrupt customary water rights and organizations; insecure tenure

Participation is costly; multiple government units and agencies

Local water allocation practices accommodated, e.g. shares and time-based allocation

Representation in decisions, in multiple forums, especially during crises

Local and scientific expertise to demystify information

Efficient mediation, backed by government authority

Customary water rights recognized, including local processes for dispute resolution

Community autonomy; strategic alliances 
However, other factors blur the seeming clarity of basins as management units (see, for example, Cleaver and Franks, 2003). Administrative jurisdictions, such as districts and provinces, cross-cut basins. Resource users engage in activities inside and outside of basins. Within basins, conditions are not uniform: shortages become severe at particular times and places, meaning that specific sub-areas will be much more concerned about particular problems. Regulation of land-use changes that affect water flows engages different sets of people and agencies. Health agencies hold responsibilities for water quality, while environmental agencies and organizations pursue agendas for conservation. Groundwater basins overlap surface basins. Irrigators steer water around hillsides, moving water between different sub-basins and basins, as do cities reaching out to expand their water supplies. Physical linkages within a basin offer a foundation for management, but social and economic linkages follow different patterns, raising the transaction costs of coordination.

Conceptual frameworks for integrated water resources management (IWRM: Agarwal et al., 2000; Rogers and Hall, 2000) offer the appealing prospect of coordinating solutions to many of these complexities, but may presume or be interpreted to require ambitious projects for design and implementation of elaborate new institutional arrangements. From a community perspective, if negotiation is costly it may be most important to engage those most affected by, and able to contribute to, in solving an immediate problem and crafting coalitions within and between communities. Thus, the most relevant scope may cover a problemshed (Halaele and Knesse, 1973) rather than necessarily including an entire river basin or comprehensively integrating water resources management. Rather than clearly defined boundaries and complete membership, the immediate challenge from a community perspective may be to form an ad hoc coalition among a fuzzy set (Kosko, 1994) of people with widely differing stakes in a problemshed.

\section{Proportionality between costs and benefits}

Within communities, access to shared water infrastructure for household or irrigation use is usually linked with obligations to contribute to investment, or at least maintenance. However, government subsidies for water infrastructure often encourage expectations of receiving benefits without paying costs. From an economic perspective, raising water prices may appear to be a logical way to link costs and benefits. However, users are likely to oppose formalization of water rights if it is seen as primarily a means to impose new charges.

Few governments have enough political power to establish themselves as water lords, extracting marginal cost prices for water, although recovery of some operation and maintenance costs may be feasible. Alternatively, tradable water rights could open a politically more feasible pathway to voluntary win-win exchanges. However, establishing tradable rights requires working through a variety of complex issues, resolving conflicts and clarifying rights, as well as developing institutions for more precise water accounting and protection of third parties.

Shifting to volumetric water allocation of surface water offers theoretical benefits, and practical problems in measurement and control that grow larger as the volumes involved become smaller. From a community perspective, arrangements that accommodate existing local practices - such as proportional sharing of shortages and measuring water based on time rather than volume - are likely to be much more feasible and acceptable than drastic changes in how water is measured and priced.

\section{Collective-choice arrangements}

The scale of basins prevents direct participation of all stakeholders, but representation risks reinforcing biases (Wester et al., 2003). The danger that participatory platforms (Boelens et al., 1998; Steins and Edwards, 1998) are co-opted, manipulated and lack meaningful decisionmaking power makes it wiser to take a selective and strategic approach to participation and coalition-building, carefully considering whether or how to 'come to the table', and retaining options to employ a mix of strategies in multiple forums. ${ }^{14}$ Representation is most crucial during crises, such as droughts, when modifications in water allocation rules receive urgent attention. 


\section{Accountable monitoring}

Communities lack information about conditions elsewhere in a basin. Agencies with monopoly control over infrastructure may escape accountability, and tend to develop information systems primarily to serve their internal purposes. Advances in information technology promise abundant information, accompanying problems of information overload and difficulty in understanding the complex impact of land-use changes, return flows and other factors on water availability. Local and outside experts can help demystify knowledge, improving the capacity of communities to make and monitor agreements.

\section{Graduated sanctions and conflict-resolution mechanisms}

Rights mean little unless there are ways to enforce them when they are infringed and, as the legal saying goes, 'there is no right without a remedy'. The asymmetry of water flowing downhill lets upstream users act without consideration of the consequences for those downstream, a lack of reciprocity that impedes the emergence of self-enforcing cooperation. Lack of social ties between distant communities further limits the potential influence of sanctions based on reputation and repeated interaction. A framework of government authority can enable strangers to contract credible commitments (North, 1990), and this can include agreements about government-recognized water rights. However, legal proceedings that are prolonged, costly, hard to enforce or construed in ways that fit poorly with the practical needs of water management often make courts problematic for resolving conflicts, although they sometimes offer useful bargaining leverage (see, for example, Sengupta, 2000).

If effective conflict resolution mechanisms and sanctions are absent, then problems such as unchecked upstream abstraction and mining of aquifers may be inevitable (Shah et al., 2001; Shah, Chapter 5, this volume). Conditions in many basins mean that having any form of effective recourse is a higher priority for communities than minimizing transaction costs or precisely calibrating sanctions. In the absence of effective alternatives, mediation by government authorities typically plays a central role in deal- ing with disputes over water, and mediation processes can be further improved.

\section{Rights to organize}

Formalization of water user associations in government-driven projects sometimes does more to disrupt than to sustain local collective action in irrigation (Bruns, 1992; Mosse, 2003; Shah, 2004). Constitutional and legislative provisions asserting government sovereignty over natural resources, including water, are often construed to ignore or deny community rights rather than recognizing customary rights and the pluralism of different forms of rights to water. However, advocates can develop other legal interpretations that support communitybased property rights (including both common and individual rights derived from community rights) (Lynch, 1998).

Various legal mechanisms are available by which customary rights can be recognized, with legal standing, without requiring formal registration. As one example, Japan's River Law includes transitional clauses stating that existing users are 'deemed' to have permission, and must be so treated, without requiring a formal permit (IDI, 1997; Sanbongi, 2001). ${ }^{15}$ Such legal frameworks establish a default situation where community rights are recognized. The burden of proof would then lie with those who would seek to challenge such rights, or processes that may seek to balance their claims against others. For communities, finding ways to assert customary community rights may well be more important than establishing a government-prescribed organization or formal registration of water rights.

\section{Nested organizations}

The logical structure of basins, sub-basins and localities invites multiple layers of organization, but makes no guarantee that such a hierarchy will be effective, worthwhile or even feasible (Ravnborg, 2004). Water rights systems may be more successful and reduce transaction costs by avoiding government micro-management of water allocation within communities (Guillet, 1998). Legal frameworks can enable 
the formation of special districts, with the necessary authority to manage water and mobilize funds, while leaving it up to water users to initiate polycentric organizations on scales that fit their needs and capabilities (Blomquist, 1992). ${ }^{16}$ Even if local government jurisdictions mismatch hydraulic boundaries, some support from local authorities will probably be essential to put new or modified rules into practice. From a community perspective, local autonomy and external alliances are likely to be more important than establishing elaborately nested organizations.

If principles for institutional design are interpreted as necessary conditions for coordinating water use within basins, then the limiting and complicating conditions reviewed above might be used to conclude that participatory governance will be impossible. Even if institutional design principles are interpreted more modestly, as desirable conditions that favour good management, they still highlight the many challenges facing basin water management and the need to customize and prioritize how principles are applied. In most cases, especially in the short term, it is unlikely that all or even many of the principles will be completely fulfilled. The question then becomes not one of prescriptively designing an ideal institution, but one of what communities, agencies and other actors in water governance, improvising institutional design as insiders, might accomplish under the conditions that actually prevail.

\section{Aiding Community Negotiation}

Water users who want to negotiate water rights may choose various means to pursue their interests. They may study relevant statutes and regulations and gather other information on their own about water problems and potential solutions. They may organize themselves, working through existing local organizations or forming new organizations and coalitions. They may share experiences and coordinate with other groups, through informal contacts and more structured activities such as conferences or workshops. They may participate in planning activities related to water allocation. They may advocate their interests through the media or by directly lobbying politicians and agency officials. They may establish forums covering broader areas such as a basin or sub-basin and develop such organizations to provide effective platforms for negotiation.

Complementing the means available to water users are various measures available to improve community participation in basin governance. Table 3.4 summarizes potential programme interventions from a government perspective and potential community priorities.

\section{Legislative reform}

Legal frameworks can empower existing user communities if their rights are recognized and backed by legal recourse if rights are harmed. Legal reforms that provide formal water rights and legal status for user organizations may be useful in providing legal standing to sue in courts or to participate in administrative procedures, strengthening strategic options for litigation and participation. Stronger rights to resources may be very valuable over the long term, not just for encouraging investment but more directly by empowering people to protect and improve their livelihoods (de Soto, 2000). More generally, transparency, accountability and other characteristics of the rule of law in good governance provide conditions that enable stakeholders to act more effectively to protect their interests.

However, from a community perspective, one major problem is that legislative reforms take a long time. Passage of new legislation requires the construction of political coalitions: institutional bargaining that is often contingent on propitious circumstances may be more a matter of luck than of planning. Political conditions and coalitions shape the space available for institutional changes. If reforms are enacted, they may

Table 3.4. Priorities for support programmes.

\begin{tabular}{ll}
\hline Government perspective & Community priorities \\
\hline Reform laws and policies & $\begin{array}{c}\text { Rights, recourse } \\
\text { procedures } \\
\text { Paralegals, legal aid }\end{array}$ \\
$\begin{array}{ll}\text { Legal education } & \text { Meaningful livelihoods } \\
\text { Technical analysis } & \text { Community experts } \\
\text { Facilitating organizations } & \text { Networks, coalitions } \\
\text { Participatory platforms } & \text { Authority, strategic allies }\end{array}$ \\
\hline
\end{tabular}


make a big difference, or not. Even after legislation is passed, implementing regulations are often needed. Government agencies may or may not be active about applying what has been put into law. If ambiguities or conflicts exist with other legislation, then legal rulings or amendments may be needed. Nevertheless, even with carefully drafted legislation, if courts are unable or unwilling to enforce legislation then regulation of social and environmental externalities is difficult (Bauer, 2004). For communities, minor modifications of existing regulations on the one hand, and long-term rights to resources on the other, may be more important than the mediumterm policy reforms that attract much attention from researchers and reformers.

\section{Legal empowerment}

Legal aid, legal education and related approaches, sometimes referred to as legal literacy or legal empowerment, cover a range of activities for improving the capacity of people to understand and use legal systems (Lynch, 1998; Harwell and Lynch, 2002). This includes opportunities for creative use and reinterpretation of existing national and international law. Even if legal protection for local rights is weak, ambiguous or uncertain, litigation may still play a useful role in combination with other strategies for defending community access to water.

While conventional 'rule of law' efforts to develop good governance tend to focus on courts, lawyers and government officials, legal empowerment approaches emphasize improving the capacity of communities to know and use the law (Golub, 2003). Local people who develop some expertise can play crucial roles as paralegals. Legal aid may be provided by nongovernmental organizations, law schools and government programmes (see, for example, NNMLS, 2000). Habits, concepts and prejudices sometimes lead disputants to behave in ways that may not be conducive to reaching agreement. Specific techniques, such as interest-based negotiation and assistance from facilitators or mediators, may play a valuable role.

For communities whose water rights are under immediate threat, legal empowerment measures offer some of the most promising opportunities. A first challenge is to enable communities to link with sources of assistance. Media publicity and networking, for example through civic organizations, may play a key role. The second challenge, and probably the main constraint, is the availability of resources, such as funds and skilled lawyers. Usually, governments are not particularly enthusiastic about providing resources to those who want to challenge agency actions. Legal empowerment requires detailed work on the ground, much less exciting and much more prone to failure than advocacy.

In practice, it requires lots of compromise, deciding which struggles to prioritize, which goals seem achievable, working with government officials and seeing what can be done within the constraints of an existing system. What may be most relevant for communities is to have knowledgeable local people and outside counsellors who know the existing legal framework, and what bases it may offer communities for securing water rights.

\section{Advocacy}

Advocacy draws attention to community concerns, concepts and roles in the management of water. Outside groups may provide links with reporters, document problems, convene forums to discuss issues and strengthen capability to prepare and deliver messages. Advocacy can open access to additional forums for defining community rights to water. If links can be obtained to media or decision makers, then advocates may be able to mobilize allies and reframe issues in ways that favour community concerns. Advocates may play influential roles in policy debates at the national and international level.

Non-governmental organizations (NGOs), local communities and others concerned about adverse impacts on communities have played major roles in blocking the passage of new water laws in countries such as Thailand, Sri Lanka, Peru and Ecuador (Gunatilake and Gopalakrishnan, 2002; Trawick, 2003; Bauer, 2004 , p. 146). In the case of Indonesia's recent water law, key provisions regarding water rights were revised with intentions of better protecting poor farmers' access to water, in response to concerns of NGOs, academics and some parliamentarians. 
However, communities themselves cannot earn a living from advocacy, and rather than endless ideological struggle they are likely to prefer pragmatic engagement that expands meaningful opportunities. Governments and NGOs may focus on protecting subsistence, while communities also want to gain the benefits of new technologies and markets. Time scales for local advocacy may differ from those of organizations that would like to aid them. On the one hand, communities want pragmatic solutions to immediate problems, and so may have less interest in medium-term struggle for policy reform and intricate basin planning. On the other hand, communities may pursue their efforts over decades or even centuries outliving opponents, overcoming temporary setbacks and applying patient persistence to achieve their local objectives (Maass and Anderson, 1978).

\section{Technical advice}

Lack of technical information is often a key constraint. For example, technical analysis can help to clarify how much water is available and how it is being used. This may help correct misconceptions and focus attention more precisely on feasible solutions. Participatory rural appraisal, participatory geographic information systems, scenario models and related methods offer a variety of techniques for blending local and outside knowledge in ways that can be relatively fruitful and efficient in terms of local people's time. Information technologies such as remote sensing, databases, modelling, $e$-mail and web sites are reducing the costs of monitoring, but they still face constraints including limited funding for acquiring data, scientific uncertainty and information overload for those who want to use such data.

Information may be useless if it seems irrelevant, incomprehensible or confusing. A few people within a community may be interested and able to learn deeply about an issue, but most people are busy with their lives and are not interested in becoming technical experts. Specific studies focused on problems perceived as important and framed in ways that reflect community concerns are much more likely to be worthwhile than more academic and general research. For a community, an attractive option may be to have their own experts, both local and external, to counter - at least partially - the weight of expertise that government agencies can mobilize.

\section{Networking}

Establishing and strengthening of local organizations can be facilitated by outside assistance. However, in dealing with basin- and sub-basinscale issues, strengthening of external links may be more crucial. Networking between communities cross-fertilizes experiences and enables coordinated efforts. As discussed earlier, one of the main challenges for water management is the scale of conflicts that can extend across broad areas. Local people may be able to make use of existing linkages with other areas, through relatives and friends living elsewhere, formal organizations and political and other contacts. Outsiders may be in a good position to foster linkages between distant groups with few existing connections, creating 'bridging' social capital (Putnam, 1993). An outside organization may be able to convene a workshop, seminar or other activity that brings people together across a basin or sub-basin. This may facilitate constructing coalitions for coordinated efforts to pursue shared or complementary interests.

However, networking for its own sake risks dissipating time and energy on prolonged discussion. Reforms that offer a voice in consultation processes but not genuine power, e.g. representation on advisory basin committees, may be useful, or may consume effort out of proportion to outcomes, especially if they require high costs in time and money to congregate dispersed networks of participants. Networks might be most useful when engaged for specific objectives, such as sharing solutions, lobbying government agencies and legislatures, or coordinating responses to a crisis.

\section{Participatory planning}

Opportunities can be opened for communities to take part in preventing and resolving problems, increasing input from stakeholders, promoting dialogue, facilitating joint problem solving and structuring processes through which 
decisions can be made jointly with user representatives. For water rights, this may apply across a range of activities from managing a particular crisis, seasonal planning for water allocation during periods of scarcity to long-term basin planning. A 'participation audit' could assist an agency to assess the ways it allows and supports participation, and to determine whether stronger, more empowering participation may provide greater incentives for stakeholders. Stakeholders may not know about opportunities for participation and, even when they do, they may be sceptical about what potential there is for genuine influence. Signs of credibility, such as participation of senior agency staff and honesty about how final decisions will be made, may provide important signals.

Methods for reducing the transaction cost of participation, particularly the time required, can make a difference, for example by providing information, accepting input and engaging in dialogue through multiple forms, rather than restricting interaction to a single stylized approach such as conventional public hearings. Many efforts labelled as participation or decentralization fail to convey genuine power, while others that do transfer power, money and other resources fail to consider the risks of local abuse, inequities, overexploitation of resources and other problems. A key question is: 'who decides?' Empowerment is far more meaningful if both sides must agree, or when decisions are delegated, authority transferred or local institutions enabled to make decisions on their own, while governments and civil society act to provide appropriate regulatory checks and balances.

\section{Platforms}

Availability of particular forums or platforms (Steins and Edwards, 1998; Boelens and Hoogendam, 2002) can make negotiation possible, providing focused arenas within which problems can be discussed, alternatives considered and agreements formulated. This may occur as part of other activities, as discussed earlier in terms of participatory planning, or through establishment of special-purpose organizations, such as alliances of concerned groups, basin committees or water councils. Groups can be brought together to discuss issues and consider establish- ing arrangements for cooperation. Facilitators may help to convene stakeholders and strengthen organizations.

However, ostensibly neutral processes convening stakeholders to create consensus, based on shared information and improved communication, risk perpetuating and worsening existing differentials in power, wealth and status (Edmunds and Wollenberg, 2001). Rather than using a pure strategy of relying on a single forum, communities may want to employ a mixed strategy of working through multiple forums and asserting multiple bases for their claims to water. Outsiders intending to preferentially aid particular groups, e.g. poor people, women, ethnic minorities or other disadvantaged groups, may want to take a careful and strategic approach to the development of platforms, as may communities themselves. A strategic approach to platforms may involve selective alliances, controlling release of information about community conditions and objectives, waging struggles in multiple forums, opportunistically improvising responses to particular events and accepting pragmatic compromises conceived of as only temporary concessions during continuing contests over rights and resources.

\section{Concluding Conjectures}

Critical analysis of community-based natural resources management and institutional design principles provides a basis for proposing some working hypotheses ${ }^{17}$ about how communities may be expected to act to secure rights to water. These may help to understand how communities may act to defend customary rights to water, and to manoeuvre within a plural framework of national and local laws and other normative orders regulating access to water, and the potential results of changes in institutional arrangements. Conjectures about priorities, principles and programmes need to be customized to specific contexts where communities are involved in basin water governance, but they may offer some practical starting points for discussion, research and practical application. Realistic expectations about community priorities may reduce the risks of waste, disruption and disappointment due to inappropriate interventions. 
Critiques of community-based natural resources management and of institutional design principles clarify some of the challenges and constraints to interventions intended to change water allocation institutions. The scale of competition over water makes negotiation of credible agreements (commitments) contingent on the availability of government enforcement. Coalitions and compromises to forge cooperation among heterogeneous users may reflect and amplify differences due to wealth, power, gender, ethnicity and other characteristics, unless there are particular countervailing conditions and arrangements that promote equity. Political contests over claims to water, budgets and related resources often impel participatory reforms more towards allowing a voice in agency decisions than towards partnership (where both sides would have a veto) or fuller empowerment of communities.

Principles for institutional design can be made more applicable by suitable adaptation to the context of community perceptions and practical priorities. Communities may be more concerned about: (i) problemsheds than hydrologic catchments; (ii) protecting local practices more than precise proportionality of rights, costs and benefits; (iii) representation during crises more than participation in deliberative platforms; (iv) effective recourse to remedy harm to rights more than carefully calibrated sanctions; (v) administrative mediation more than consensual forums or courts; (vi) recognition of customary rights more than formal registration; and (vii) local autonomy and strategic coalitions with local governments and other allies more than elaboration of nested hydraulic enterprises.

A community perspective on water governance suggests that the dynamics of community collective action to secure water rights are likely to be:

- Primarily defensive, concerned with protecting against threats to existing claims.

- Constructed of heterogeneous coalitions, within and between communities.

- Employing mixed strategies using multiple claims and forums.

- Opportunistically improvised in response to particular crises.

Therefore, interventions aimed at optimizing and reallocating water use, assuming shared interests, attempting to monopolize water allocation decisions in a single forum, and pursuing comprehensive, anticipatory planning, such as ambitious projects for basin master planning, and IWRM, may fit poorly with the dynamics of community collective action, and so they may be prone to being ignored, resisted and rejected. Modest institutional modifications that fit the dynamics of community collective action and help secure rights and resolve urgent crises may meet with greater success.

Interventions in basin governance intended to support community-based natural resources management and strengthen local organizations may have better prospects if carefully fitted to the contours of institutional landscapes and oriented towards promising pathways for institutional transformation. From a community perspective, short-term regulatory adjustments that solve immediate problems and long-term rights to resources may be more important than medium-term reforms to build basin management organizations. Targeted training for local paralegals and access to legal aid may do more to make laws effective than extensive broadcasts, brochures and lectures.

Facilitating strategic links to outside groups and agencies may do much more for community capacity than intensive internal organizational development. Lobbying in opposition to changes that threaten to further disadvantage people may be helpful, but advocacy that pragmatically expands meaningful opportunities for people to sustainably improve their lives may accomplish even more. Participatory planning that honestly promises influence over decisions creates credibility, but empowerment that establishes partnerships, delegates decisions, transfers authority or enables autonomy (within appropriate regulatory checks and balances) may do even more to improve basin resource governance.

Information technologies are expanding availability of information but, to make abundant information useful, communities need local and external expertise to apply knowledge to serve their objectives. Platforms may facilitate formation of acceptable agreements but they may be only part of developing a portfolio of community strategies to negotiate rights to water. 


\section{Endnotes}

1 Communities as used here include villages, irrigators' organizations and other groups of people acting collectively, and may include not only small face-to-face groups where all members know each other, but also larger groupings, for example based on shared ethnic identity and social relationships. For an example of such larger communities in the Andes, see Boelens et al., Chapter 6, this volume.

2 For a discussion of negotiation of American Indian water rights, see Checchio and Colby (1993); McCool (1993, 2002); Colby et al. (2005). Danver (2004) compares three strategies: litigation, participation in project planning and negotiation, used by three American Indian groups in New Mexico, noting the tendency of different strategies to converge into similar processes.

3 For a discussion of various levels and scales of participation, following Arnstein's original (1969) 'ladder of participation', see Bruns (2003).

4 It is also important to distinguish clearly decentralization that deconcentrates power to local branches of central government from devolution that actually shifts authority (including authority over funding and conflict resolution) to local bodies.

5 See, among others, Agrawal and Gibson (2001), for a review of community-based conservation, Agrawal (2003), for a recent review of research on common-pool resources management and Mansuri and Rao (2005), for a recent synthesis of peer-reviewed studies of community-based and community-driven development and related approaches.

6 For a nuanced empirical and theoretical discussion of conflicts in Balinese subaks see Spiertz (2000).

7 Fisher et al. (1991) define power in negotiation operationally in terms of the 'best alternative to a negotiated agreement' (BATNA) - in other words, the 'fallback position', the outcome that a party could obtain if agreement is not reached.

8 Mansuri and Rao (2005) note that elite control may be almost inevitable. As apparent in most of the literature, they use the notion of 'capture' in a rather unexamined way. Capture is assumed to be undesirable and detrimental, and not clearly distinguished from other forms of local political support or 'buy-in'. The literature does not seem concerned about the finding from the study of regulated industries that capture by regulated interests may be a less important phenomenon than the tendency of new institutions to pursue their bureaucratic interests in expanding budget, staff and authority ('turf'). Similarly, analysis of 'elite' roles might benefit from more attention to competition within and between elites, and the 'circulation of elites'.

9 For co-production, see Lam (1997); Ostrom (1997). Berkes (1994) discusses co-management. For regulated autonomy, see Ribot (2002); Bruns (2003).

10 For institutional 'fit' see Young (2002).

11 Hardin's (1998) commentary belatedly corrected his earlier (1968) article to clarify that the tragedy is a problem for 'unmanaged' commons, those without effective institutional arrangements (state or community) to regulate access.

12 Cleaver and Franks (2003); see also Lévi-Strauss' original discussion of bricolage (1966 [1962]) (available at http://varenne.tc.columbia.edu/bib/ info/levstcld066savamind.html).

13 It should be clear that the emphasis in this chapter is on community priorities and institutional arrangements that may be effective in meeting their priorities. This need not necessarily mean that these are the arrangements that would be the most economically efficient, socially equitable, ecologically sustainable or institutionally robust, or the ones that would best serve the interests of other stakeholders or the entire society. The intention here is to highlight relevant institutional options from a community perspective, within a larger landscape of social contestation concerning resource management.

14 Edmunds and Wollenberg (2001) critique the neutrality and inclusiveness of forums. For challenges in transferring meaningful authority over irrigation management, see Bruns (2003) and Vermillion (2005). 'Shopping' among forums need not require choosing only one forum: instead, a disputant may employ a portfolio (or basket) of forums, i.e. a mixed strategy.

15 It should be noted that this provision provides a way for such recognition of existing use to occur within a civil law system, which does not offer the same means for recognizing past practices as would be available within a common law system.

16 For polycentric governance, see Ostrom (1997). Applications to water resources include Ostrom (1990, 1992); Blomquist (1992); Tankimyong et al. (2005).

17 The ideas developed here are offered as conjectures, suggesting what might be the most likely (initial or 'prior') expectations based on currently available knowledge, subject to customization, testing and refutation or revision based on additional information. Thus, for example, rather than naively expecting an equal (or even pro-poor) per capita distribution of benefits, it seems more likely (i.e. an appropriate working assumption or null hypothesis) to start from an expectation that 
outcomes will probably reproduce existing distributions of power and benefits (or skew them even more) unless countervailing measures are employed. From a practical perspective, particularly interesting questions then concern the extent to which outcomes may be affected by specific measures such as targeting, empowerment and advocacy.

\section{References}

Agarwal, A., delos Angeles, M.S., Bhatia, R., Chéret, I., Dávila-Poblete, S., Falkenmark, M., Fernando, G.V., Jønch-Clausen, T., Aqt Kadi, M., Kindler, J., Rees, J., Roberts, P., Rogers, P., Solanes, M. and Wright, A. (2000) Integrated Water Management. Global Water Partnership, Denmark.

Agrawal, A. (2003) Sustainable governance of common-pool resources: context, methods and politics. Annual Review of Anthropology 32, 243-262.

Agrawal, A. and Gibson, C.C. (2001) The role of community in natural resource conservation. In: Agrawal, A. and Gibson, C.C. (eds) Communities and the Environment: Ethnicity, Gender, and the State in Community-Based Conservation. Rutgers University Press, New Brunswick, New Jersey.

Anderies, J.M., Janssen, M.A. and Ostrom, E. (2003) Design principles for robustness of institutions in socialecological systems. Presented at Joining the Northern Commons: Lessons for the World, Lessons from the World, Anchorage, Alaska.

Bauer, C.J. (2004) Siren Song: Chilean Water Law as a Model for International Reform. Resources for the Future, Washington, DC.

Berkes, F. (1994) Co-management: bridging the two solitudes. Northern Perspectives 22, 2-3.

Blomquist, W. (1992) Dividing the Waters: Governing Groundwater in Southern California. Institute for Contemporary Studies, San Francisco, California.

Boelens, R. and Hoogendam, P. (eds) (2002) Water Rights and Empowerment. Van Gorcum, Assen, Netherlands.

Boelens, R., Dourojeanni, A., Duran, A. and Hoogendam, P. (1998) Water rights and watersheds: managing multiple water uses and strengthening stakeholder platforms. In: Boelens, R. and Dávila, G. (eds) Searching for Equity: Conceptions of Justice and Equity in Peasant Irrigation. Van Gorcum, Assen, Netherlands.

Bruns, B. (1992) Just enough organization: water users' associations and episodic mobilization. Visi: Irigasi 1992, 33-41.

Bruns, B. (1993) Promoting participation in irrigation: reflections on experience in Southeast Asia. World Development 21, 1837-1849.

Bruns, B. (2003) Water tenure reform: developing an extended ladder of participation. Presented at Politics of the Commons: Articulating Development and Strengthening Local Practices, Chiang Mai, Thailand.

Bruns, B. and Meinzen-Dick, R. (eds) (2000) Negotiating Water Rights. Vistaar, New Delhi, India.

Bruns, B. and Meinzen-Dick, R. (2001) Water rights and legal pluralism: four contexts for negotiation. Natural Resources Forum 25, 1-10.

Checchio, E. and Colby, B. (1993) Indian Water Rights: Negotiating the Future. Water Resources Research Center, University of Arizona, Tucson, Arizona.

Cleaver, F. and Franks, T. (2003) How institutions elude design: river basin management and sustainable livelihoods. Presented at The Alternative Water Forum, Bradford, UK.

Colby, B.G., Thorson, J.E. and Britton, S. (2005) Negotiating Tribal Water Rights: Fulfilling Promises in the Arid West. University of Arizona Press, Tucson, Arizona.

Danver, S.L. (2004) Liquid assets: a history of tribal water rights strategies in the American Southwest. PhD thesis, University of Utah, Salt Lake City, Utah.

de Soto, H. (2000) The Mystery of Capital: Why Capitalism Triumphs in the West and Fails Everywhere Else. Bantam Press, London.

Edmunds, D. and Wollenberg, E. (2001) A strategic approach to multi-stakeholder negotations. Development and Change 32, 231-253.

Fisher, R., Ury, W. and Patton, B. (1991) Getting to Yes: Negotiating Agreement without Giving in. Penguin, New York.

Golub, S. (2003) Beyond Rule of Law Orthodoxy: the Legal Empowerment Alternative. Carnegie Endowment, New York. 
Guillet, D. (1998) Rethinking legal pluralism: local law and state law in the evolution of water property rights in northwestern Spain. Comparative Studies in Society and History 40, 42-70.

Gunatilake, H.M. and Gopalakrishnan, C. (2002) Proposed water policy for Sri Lanka: the policy versus the policy process. Water Resources Development 18, 545-562.

Haefele, E.T. and Kneese, A.V. (1973) Residuals management, metropolitan governance, and the optimal jurisdiction. In: Haefele, E.T. (ed.) Representative Government and Environmental Management. Johns Hopkins University Press, Baltimore, Maryland.

Hardin, G. (1968) The tragedy of the commons. Science 162, 1243-1248.

Hardin, G. (1998) Extensions of 'the tragedy of the commons'. Science 280, 682-683.

Harwell, E.E. and Lynch, O.J. (2002) Whose Resources? Whose Common Good? Towards a New Paradigm of Environmental Justice and the National Interest in Indonesia. Center for International Environmental Law, Washington, DC.

IDI (Infrastructure Development Institute, R.B., Ministry of Construction, Japan) (1997) The River Law (as Amended in July 1997, English Translation). Infrastructure Development Institute, Tokyo.

Knox, A. and Meinzen-Dick, R. (2001) Collective Action, Property Rights and Devolution of Natural Resources Management: Exchange of Knowledge and Implications for Policy. A workshop summary paper, International Food Policy Research Institute, Washington, DC.

Kosko, B. (1994) Fuzzy Thinking: the New Science of Fuzzy Logic. Hyperion, New York.

Lam, W.F. (1997) Institutional design of public agencies and coproduction: a study of irrigation associations in Taiwan. In: Evans, P. (ed.) State-Society Synergy: Government and Social Capital in Development. University of California Press, Berkeley, California, pp. 11-47.

Lévi-Strauss, C. (1966) The Savage Mind. University of Chicago Press. Chicago, Illinois.

Lynch, O.J. (1998) Law, pluralism and the promotion of sustainable community-based forest management. Unasylva 49, 194-207.

Maass, A. and Anderson, R.L. (1978) ... and the Desert Shall Rejoice: Conflict, Growth and Justice in Arid Environments. MIT Press, Cambridge, Massachusetts.

Mansuri, G. and Rao, V. (2005) Community-based and -driven development: a critical review. The World Bank Research Observer 19, 1-39.

McCool, D. (1993) Indian water settlements: the prerequisites of successful negotiation. Policy Studies Journal $21,227-242$.

McCool, D. (2002) Native Waters: Contemporary Indian Water Settlements and the Second Treaty Era. University of Arizona Press, Tucson, Arizona.

Mosse, D. (2003) The Rule of Water: Statecraft, Ecology, and Collective Action in South India. Oxford University Press, New Delhi, India.

NNMLS (Northern New Mexico Legal Services) (2000) Acequias and water rights adjudications in northern New Mexico. In: Bruns, B. and Meinzen-Dick, R. (eds) Negotiating Water Rights. Vistaar, New Delhi, India.

North, D.C. (1990) Institutions, Institutional Change and Economic Performance. Cambridge University Press, New York.

Olson, M. (1971) The Logic of Collective Action: Public Goods and the Theory of Groups. Harvard University Press, Cambridge, Massachusetts.

Ostrom, E. (1990) Governing the Commons: the Evolution of Institutions for Collective Action. Cambridge University Press, Cambridge, UK.

Ostrom, E. (1992) Crafting Institutions for Self-Governing Irrigation Systems. Institute for Contemporary Studies Press, San Francisco, California.

Ostrom, E. (1997) Crossing the great divide: coproduction, synergy, and development. In: Evans, P. (ed.) State-Society Synergy: Government and Social Capital in Development. University of California Press, Berkeley, California, pp. 85-118.

Ostrom, E. (1999) Coping with tragedies of the commons. Annual Review of Political Science 2, 493-535.

Putnam, R.D. (1993) Making Democracy Work: Civic Traditions in Modern Italy. Princeton University Press, Princeton, New Jersey.

Ravnborg, H.M. (2004) Water management and the poor - organizing to (re)gain access to water in the Nicaraguan hillsides. Presented at the Tenth Biennial Conference of the International Association for the Study of Common Property, Oaxaca, Mexico.

Ribot, J.C. (2002) Democratic Decentralization of Natural Resources: Institutionalizing Popular Participation. World Resources Institute, Washington, DC.

Rogers, P. and Hall, A.W. (2000) Effective Water Governance. Global Water Partnership, Denmark. 
Sanbongi, K. (2001) Formation of case law and principles in watershed management. In: Bogdanovic, S. (ed.) Proceedings of the Regional Conference on the Legal Aspects of Sustainable Water Resources Management. International Association for Water Law, Novi Sad, Serbia, pp. 121-127.

Sengupta, N. (2000) Negotiation with an under-informed bureaucracy: water rights on system tanks in Bihar. In: Bruns, B. and Meinzen-Dick, R. (eds) Negotiating Water Rights. Vistaar, New Delhi, India.

Sengupta, N. (2004) Common mistakes about common property. Paper prepared for the Tenth Biennial Conference of the International Association for the Study of Common Property, Oaxaca, Mexico.

Shah, T., Makin, I. and Sakthivadivel, R. (2001) Limits to leapfrogging: issues in transposing successful river basin management institutions in the developing world. Intersectoral Management of River Basins, Proceedings of an International Workshop on 'Integrated Water Management in Water-Stressed River Basins in Developing Countries: Strategies for Poverty Alleviation and Agricultural Growth', Loskop Dam, South Africa, 16-21 October 2000. International Water Management Institute (IWMI) and German Foundation for International Development (DSE), Colombo, Sri Lanka.

Spiertz, H.L.J. (2000) Water rights and legal pluralism: some basics of a legal anthropological approach. In: Bruns, B. and Meinzen-Dick, R. (eds) Negotiating Water Rights. Vistaar, New Delhi, India.

Steins, N.A. and Edwards, V.M. (1998) Platforms for collective action in multiple-use CPRs. Presented at Crossing Boundaries, the Seventh Annual Conference of the International Association for the Study of Common Property, Vancouver, British Columbia, Canada.

Tankimyong, U., Bruns, P.C. and Bruns, B.R. (2005) The emergence of polycentric water governance in northern Thailand. In: Shivakoti, G., Vermillion, D., Lam, W.F., Ostrom, E., Pradhan, U. and Yoder, R. (eds) Asian Irrigation in Transition: Responding to Challenges. Sage, New Delhi, India.

Trawick, P. (2003) Against the privatization of water: an indigenous model for improving existing laws and successfully governing the commons. World Development 31, 977-996.

Vermillion, D.L. (2005) Irrigation sector reform in Asia: from 'patronage with participation' to 'empowerment with accountability'. In: Shivakoti, G., Vermillion, D., Lam, W.F., Ostrom, E., Pradhan, U. and Yoder, R. (eds) Asian Irrigation in Transition: Responding to Challenges. Sage, New Delhi, India.

Wester, P., Merrey, D.J. and Lange, M.D. (2003) Boundaries of consent: stakeholder representation in river basin management in Mexico and South Africa. World Development 31, 797-812.

Wolf, E. (1983) Europe and the People without History. University of California Press, Berkeley, California.

Young, O.R. (2002) The Institutional Dimensions of Environmental Change. MIT Press, Cambridge, Massachusetts. 